\title{
Narrative Indicators of Adolescents' Maladaptive Cognitive Schemas
}

\section{Наративні індикатори дисфункційних когнітивних схем підлітків}

\section{Olga Lozova \\ Dr. in Psychology, \\ Professor}

\author{
Ольга Лозова \\ доктор психологічних наук, \\ професор
}

E-mail: o.lozova@kubg.edu.ua orcid.org/0000-0002-3549-195X

\section{Olena Lytvynenko} Ph.D. in Psychology, Associate Professor

\section{Олена Литвиненко}

кандидат психологічних наук, доцент

\section{E-mail: o.lytvynenko@kubg.edu.ua orcid.org/0000-0003-2152-7285}

Borys Grinchenko University of Kyiv

18/2, Shamo Str., Kyiv, Ukraine, 02154
Київський університет імені Бориса Грінченка $\triangle$ вул. І. Шамо, 18/2, Київ, Україна, 02154

Original manuscript received September 19, 2018

Revised manuscript accepted September 21, 2019

\begin{abstract}
Introduction. The article presents the results of a study of adolescents personal narratives. The general aim of the study was to identify narrative indicators of adolescents' maladaptive cognitive schemas. This aim was achieved by virtue of realization of such tasks as: to identify the specific text categories (indicators) that indicate the maladaptive schemas and to determine the predictive power of each category (indicator). In the course of theoretical analysis, there were systematized the approaches to the understanding of personal narratives and "self-texts». There also
\end{abstract}


was generalized the concept of maladaptive cognitive schemas, and were defined textual categories which can be reflected in the narratives of people who have certain maladaptive schemas.

Methods. The methods of the empirical study were Dusseldorf Illustrated Schema Questionnaire for Children and the content-analysis of personal narratives. Statistical processing of the obtained data and determination of the predictive power of each narrative category were performed with the help of the method of recursive division trees.

Results. As a result of the empirical study was it was found that certain categories in the personal narratives of adolescents allow us to predict the manifestation of individual maladaptive schemas. There were identified narrative indicators, able to predict fourteen of the eighteen schemas. It was determined that the knowledge of narrative indicators of maladaptive cognitive schemas can be used within the psychological counseling and therapy at the stage of gathering primary information, as well as in the context of purposeful psychological impact.

Conclusions. There were described the topical prospects for further scientific development of the problem, which were to expand the categorical structure of content analysis, which would allow to find indicators of four schemas that remain unclear, as well as to widen the age range of respondents and to test the hypothesis about the existence of a link between the personal narratives of adults and their maladaptive schemas. There was made an assumption that modification of a personal narrative can accelerate therapeutic work aimed at eliminating the negative impact of maladaptive schemas on a person's life.

Key words: narrative, maladaptive schemas, core beliefs, adolescents, content analysis, narrative psychotherapy.

\section{Вступ}

Усвідомлене мовлення (як усне, так і письмове) - це одна зі специфічно людських ознак. За допомогою мовлення людина сприймає та передає інформацію, висловлює своє ставлення до навколишнього світу, проявляє емоції. Крім того, розповідаючи про себе, створюючи власні персональні тексти (наративи), мовець усвідомлює свій досвід, систематизує його та досягає власної ідентичності. Саме тому предметом даного дослідження стали особистісно-орієнтовані тексти, або персональні наративи.

Наратив - поняття психології постмодерну, яке фіксує процесуальне самоздійснення особи як спосіб буття авторського тексту (van Dijk, 2008). Представники наративного підходу присвячують увагу взаєминам автора з його персональним текстом - 
наративом (Bauer \& McAdams, 2010; Dautenhahn, 2009; Harre, 2002). В ході наукових пошукувань Т. Сарбін висуває робоче поняття персонального наративу, котрий властивий кожній людині і є при цьому нестабільним та постійно оновлюється. Базовий наратив, на думку науковця, є сутністю, що означує просторові координати та часову перспективу, в якій живе людина (Sarbin, 1986).

В сучасній психолінгвістиці вивченню механізмів відображення досвіду особистості у створених нею текстах присвячені чисельні праці. Так, дослідники говорять про відображення загальної структури «я-концепції» особистості у створених нею текстах (Кубрак, 2009), про наратив як засіб самопрезентації (Федорова, 2007) та результат інтеракції (Юрьева, 2018). Крім того, науковці вивчають представлення в персональних текстах типових для автора когнітивних (Blenkiron, 2005), поведінкових (Засєкіна, 2009) та афективних (Ионова \& Штеба, 2019) патернів.

Проблеми особливостей продукування мовцем особистісних текстів досліджуються, зокрема, Н. Чепелєвою, котра розглядає наративну психологію як таку, що має виходити 3 розуміння особистості як саморозповіді і, відповідно, особистісного досвіду як результату упорядкування, організації життєвих подій у наративні тексти. У праці «Життєвий успіх як наратив» науковиця припускає, що розповідання про життя і проживання життя $\epsilon$ за своєю суттю тим самим феноменом (Чепелєва, 2010). Таким чином, наратив являє собою трансформацію невпорядкованих життєвих подій у певну послідовність, вибудувану на основі загальної життєвої концепції оповідача, або ж його особистісного міфу, що визначає внутрішню логіку породжуваного тексту. Наслідком цього $є$ створення власного внутрішнього світу особистості, реальності, яка вибудовується як неповторне особистісне творіння за допомогою авторського ставлення до навколишньої дійсності i до власної особистості, ідентичності.

Створюючи авторські тексти, особа вкладає в них власний досвід, світоглядні та концептуальні конструкти. Окремі структурні елементи персонального наративу можуть бути індикаторами травматичного досвіду, який пережила людина та мають враховуватись при формуванні загальної стратегії психотерапевтичної роботи 3 нею (Василюк, 2014). Дослідження Л. Засєкіної свідчать, що люди, які пережили психотравмуючі події, 
схильні втілювати їх образи у власних персональних наративах. Водночас, пропрацювавши та модифікувавши наратив, що містить спогади про травматичний досвід, людина може більш швидко та ефективно подолати наслідки травми (Засєкіна, 2012). Така концепція $\epsilon$ основою наративної терапії як одного 3 сучасних методів цілеспрямованого психологічного впливу. У найширшому сенсі наративна терапія $є$ бесідою, в процесі якої особи переказують, тобто розповідають по-іншому історії свого життя. Для наративних терапевтів наратив - це події, об'єднані в певні послідовності на деякому часовому проміжку і приведені таким чином у стан наділеного змістом сюжету (Жорняк, 2005). При цьому історія кожної людини складається 3 безлічі наративів. Характер і специфіку цих наративів визначає те, на які події людина звертає найбільшу увагу, як пов'язує їх між собою і який сенс їм надає. Як свідчать результати наших попередніх досліджень, вибір подій, що відображаються у персональному наративі та загальна стилістика ïх представлення обумовлюються індивідуально-психологічними особливостями автора (Литвиненко, 2014).

У персональних наративах людина систематизує власний досвід, окреслює коло домагань, відшукує свою ідентичність та актуалізує іiі. Таким чином, наратив $\epsilon$ формою «я-тексту» особистості, тобто їі текстуальної самопрезентації. Про можливість вивчення особистісних проявів наративної суб'єктності засобами «я-тексту» говорить Ю. Масієнко, яка визначає «я-текст» як будь-які ï дискурсивні прояви, що мають на меті втілення або вираження іiі «Я». Така двоїстість «я-тексту», на думку науковиці, характеризує основні його ознаки - незавершеність та кумулятивність, що визначають його динамічну природу, оскільки «я-текст» завжди перебуває в процесі становлення (Масієнко, 2006). Аналіз «я-текстів» може бути доцільним у контексті комплексної психологічної діагностики особистості, а також в ході наукових пошукувань, спрямованих на дослідження окремих іï проявів та характеристик.

Метою дослідження стало визначення наративних індикаторів дисфункційних когнітивних схем підлітків. Ми припустили, що аналіз текстів, які продукує особистість, дозволить визначити притаманні їй дисфункційні когнітивні схеми. Реалізація мети стала можливою за рахунок виконання таких завдань: 1) виокремлення 
конкретних текстових категорій (індикаторів), які б вказували на наявність дисфункційних схем та 2) визначення прогностичної сили кожної категорії (індикатора) персональних наративів для передбачення наявності у мовця тієї чи іншої дисфункційної когнітивної схеми. Проте, перш ніж перейти до представлення результатів дослідження, варто більш детально зупинитись на проблемі дисфункційних когнітивних схем.

Так звані ранні дисфункційні схеми в широкому сенсі визначаються як загальні моделі (взірці, патерни) життя, що впливають на когніції, емоції, спогади, поведінку, особливості сприйняття соціальних ситуацій та стосунків 3 іншими людьми. Вважається, що дисфункційні схеми формуються в дитинстві (Bateman \& Fonagy, 2009). Залежно від життєвої ситуації, досвіду стосунків, індивідуальних механізмів копінгу, тобто подолання наявних труднощів, вони можуть змінюватись протягом усього життя, і часто підтримуються цими ж факторами.

За умови якщо активується наявна схема, з'являються сильні негативні емоції, такі як тривога, смуток чи відчуття самотності. Дж. Янг і співавтори (Young, Klosko \& Weishaar, 2003) визначили 18 схем, які об’єднуються у п’ять груп - «областей». Попри те, що наукові дослідження підтверджують їх існування, ці визначення дисфункційних схем були сформовані переважно в результаті клінічних спостережень, а не внаслідок емпіричних досліджень. Зазначені групи схем є такими: 1) схеми втрати зв’язку та відкидання (покинення, недовіри, емоційної депривації, дефективності, соціальної ізоляції); 2) схеми обмеженої автономії і здатності досягати успіху (залежності, очікування на катастрофу, злиття, некомпетентності); 3) схеми порушення меж (особливого статусу, недостатнього самоконтролю); 4) схеми спрямованості на інших (підкорення, самопожертви, пошуку визнання) і 5) схеми надмірної пильності та інгібіції (негативізму, емоційної інгібіції, надвисоких стандартів, покарання) (Арнц, 2014).

У будь-якої особи може бути одна схема або комбінація 3 декількох схем. Як правило, люди мають більш-менш стійкі схеми. Схема вважається патологічною лише тоді, коли пов'язана 3 патологічними емоційними переживаннями i симптомами чи порушеннями соціального функціонування. Особи 3 важкими розладами особистості зазвичай отримують високі бали за багатьма 
схемами за схема-опитувальниками Янга (Bateman \& Fonagy, 2009). Навпаки ж, особи, яким притаманні лише певні життєві труднощі, і які не відповідають діагностичним критеріям розладу особистості та мають більш високий рівень соціального функціонування, як правило, отримують високі бали лише за однією або двома схемами (Арнц, 2014).

Очевидно, що приналежність схем до когнітивної підсистеми особистості визначає їх характер та специфіку прояву. Актуалізуючись на рівні поведінки та визначаючи емоції особистості, дисфункційні схеми формуються у свідомості та відображають уявлення людини про навколишній світ та своє місце в ньому. При цьому ми можемо класифікувати схеми відповідно до ïx спрямованості на саму людини (егоцентричні) та на їі соціальне оточення (соціоцентричні). Егоцентричні схеми (особливого статусу, надвисоких стандартів, очікування на катастрофу, некомпетентності та ін.) визначають уявлення людини про себе, ii рівень домагань та специфіку побудови картин імовірнісного майбутнього. Водночас соціоцентричні схеми (залежності, підкорення, пошуку визнання та ін.) впливають на специфіку поведінки людини в соціумі та характер її взаємодії з оточенням.

Цікаво, що поняття «схема» в психологічному тезаурусі вживається одночасно для позначення дисфункційних переконань особистості, які визначають іï емоції та поведінку, а також для визначення когнітивного механізму розуміння життєдіяльності іншого індивіда та осмислення власних намірів i дій, що відбуваються в межах діяльності, спрямованої на створення людиною персональних наративів. Так, О. Нікітіна зазначає, що наративна схема $\epsilon$ пізнавальною процедурою «зчитування» потоку подій таким чином, що вони стають зрозумілими в контексті завершеної історії (Никитина, 2015). У зв'язку 3 цим можна говорити, що схема виступає як невід'ємний компонент пізнавальної та розумової активності. При цьому важливо підкреслити, що схема виступає як модель «особистісного бачення ситуації», розподілу персональних акцентів, iї стабільність також залежить від особистісних характеристик і попереднього досвіду автора (Казанцева, 2018).

Своєю чергою, дослідження Ю. Зайцевої доводять, що розгляд наративів як когнітивних схем конструювання змісту через тематичне 
розташування фактів у вигляді організованих сюжетів в соціальному та часовому просторі дозволяє інтерпретувати «я-тексти», що можуть виступати в якості інструменту конструювання своєї ідентичності (Зайцева, 2016).

Тобто саме поняття «схема», реалізуючись одночасно в межах когнітивного та наративного підходів, наштовхує на ідею дослідження на перетині цих сфер.

\section{Методи та методики дослідження}

Емпіричне дослідження, спрямоване на визначення наративних індикаторів дисфункційних схем підлітків, було проведене на базі однієї 3 київських шкіл. Загальна кількість респондентів склала 153 особи віком від 11 до 14 років. Інструментально дослідження було реалізоване з використанням Дюссельдорфського опитувальника схем для дітей (Loose, Meyer \& Pietrowsky, 2018) та контент-аналізу особистих наративів досліджуваних (Stephens \& Breheny, 2015). Статистична обробка результатів здійснювалася 3 використанням прогностичного методу дерев рекурсивного ділення.

Дюссельдорфський опитувальник схем для дітей, базуючись на загальній теорії про ранні дисфункційні схеми, дозволяє визначати глибинні переконання дітей та підлітків віком від 8 до 14 років про життя, навколишній світ та своє місце в ньому. Ілюстрації та детальні роз'яснення до кожного питання суттєво полегшують процес виконання завдань досліджуваними.

Після відповіді на запитання опитувальника досліджуваним було запропоновано написати текст про себе, тобто в письмовій формі створити власний персональний наратив. Жодних чітких вказівок, щодо структури, стилю та формату подачі інформації не надавалось. Єдиною вимогою була особистісна орієнтованість тексту. На даному етапі дослідження ми спирались на класичну тезу наративної психології про те, що створюючи власні текстові одиниці (наративи) людина виявляє особисті, принципово значущі психологічні характеристики (Sarbin, 1986).

Створені досліджуваними тексти були піддані контентаналізу, який являє собою формалізований i систематизований метод дослідження текстової та графічної інформації й полягає у переведенні інформації, що аналізується, у кількісні показники 
та подальшій iï статистичній обробці (Wooffitt, 2015). Перш ніж перейти до безпосереднього аналізу тексту, необхідно було визначити категорії цього аналізу, тобто ключові поняття (смислові одиниці), наявні в тексті та відповідні тим дефініціям i їх емпіричним індикаторам, які зафіксовані у програмі дослідження. Для аналізу особистісних наративів, написаних респондентами, було виокремлено чотири основних категорії: 1) емоції та переживання; 2) соціальна взаємодія; 3) абстрактні роздуми; 4) спрямованість. При цьому перші три категорії розподілялись на дві підкатегорії кожна відповідно до модальності (позитивної та негативної), а четверта категорія включала підкатегорії відповідно до часового виміру (спрямованість у майбутнє та спрямованість у минуле).

Таким чином, в ході подальшого аналізу отриманих результатів ми оперували вісімнадцятьма схемами та вісьмома підкатегоріями контент-аналізу. Як було зазначено, для статистичної обробки даних використовувався метод дерев рекурсивного ділення (Hothorn, Hornik \& Zeileis, 2006), який дозволив реалізувати друге завдання дослідження, а саме виявити прогностичну силу домінуючих категорій в особистих наративах для прогнозу наявності певних дисфункційних схем у досліджуваних. При цьому суть статистичного аналізу полягала в конкурентній ієрархічній оцінці даних.

Категорії контент-аналізу - це номінативні значення, які не можуть бути впорядковані за шкалою більше-менше, а показники дисфункційних схем, в даному випадку, - це числові оцінки прояву за Дюссельдорфським опитувальником. Поєднання номінативної та кількісної шкали унеможливлює використання класичної техніки регресійного аналізу, саме тому нами було обрано метод дерев рекурсивного ділення. Як відомо, результатом використання цього методу за умови чисельної вихідної змінної є середнє значення та довірчий інтервал для нього, за умови якісної (номінативної) вихідної змінної - вірогідність іiі прояву за виявлених умов. У нашому випадку прогнозувалася чисельна змінна, тобто інтенсивність прояву у досліджуваних тієї чи іншої дисфункційної схеми.

\section{Результати та дискусії}

Дослідження дисфункційних схем підлітків дозволило визначити рівень прояву цих схем. При цьому, як було зазначено, за 
відсутності патологій людина демонструє високі показники за 1-3 схемами або ж зовсім не демонструє таких показників. Високий рівень прояву чотирьох і більше схем може свідчити про порушення психічного благополуччя та, зокрема, про наявність особистісних розладів. 3 іншого боку, такі дані можуть бути зумовлені похибкою вимірювання. Тому варто не нівелювати їх діагностичне значення, але й не говорити про психічні порушення, спираючись виключно на результати стандартизованого психодіагностичного опитувальника.

В ході нашого дослідження 5 з 153 осіб продемонстрували високі і дуже високі показники за чотирма і більше схемами. Оскільки такі показники виходять за межі норми, їх було виключено з загального масиву даних, а шкільному психологу було рекомендовано провести додаткову психодіагностичну роботу 3 цими учнями. Результати інших 19 осіб свідчили відсутність у них будь-яких дисфункційних схем, що є показником їх психологічного благополуччя, але робить такі результати непридатними для подальшої статистичної обробки. Тож для статистичного аналізу було використано дані 129 досліджуваних, які продемонстрували високі показники не більш ніж за трьома схемами.

Для оцінки точності результатів було використано метод, що є традиційним для прогнозування статистичної імовірності (зокрема в регресійному аналізі), а саме квадрат похибки. При цьому окремі дерева рекурсивного ділення були побудовані для кожної підкатегорії контент-аналізу. Варто зазначити, що для трьох підкатегорій не було виявлено статистично значущого прогностичного зв'язку 3 дисфункційними схемами. До цих категорій належать «позитивні емоції та переживання» та обидві складові категорії «спрямованість» («спрямованість у майбутнє» i «спрямованість у минуле»). Прогностичний потенціал кожної 3 інших п'яти підкатегорій (див. рис. 1) варто розглянути більш детально.

Точність отриманого прогнозу для підкатегорії «негативні емоції та переживання» становить $\mathrm{R}^{2}=0,50$, що $є$ досить високим показником. Дана категорія найбільш часто трапляється в персональних наративах осіб, які мають високі показники за схемами дефективності, підкорення, очікування на катастрофу та некомпетентності. Тобто, якщо, розповідаючи про себе в неформальній бесіді або в ході психотерапевтичної сесії, підліток акцентує увагу на змалюванні тих подій, що пов'язані для нього 
3 негативними переживанням та почуттями, 3 великою мірою вірогідності можна припустити, що йому притаманна одна iз зазначених схем. Специфікацію та визначення конкретних глибинних переконань особи, при цьому, краще проводити за допомогою індивідуального структурованого клінічного інтерв'ю, оскільки саме цей метод здатен забезпечити збір якісних ідеографічних даних, на основі яких можна планувати подальші психологічні втручання.

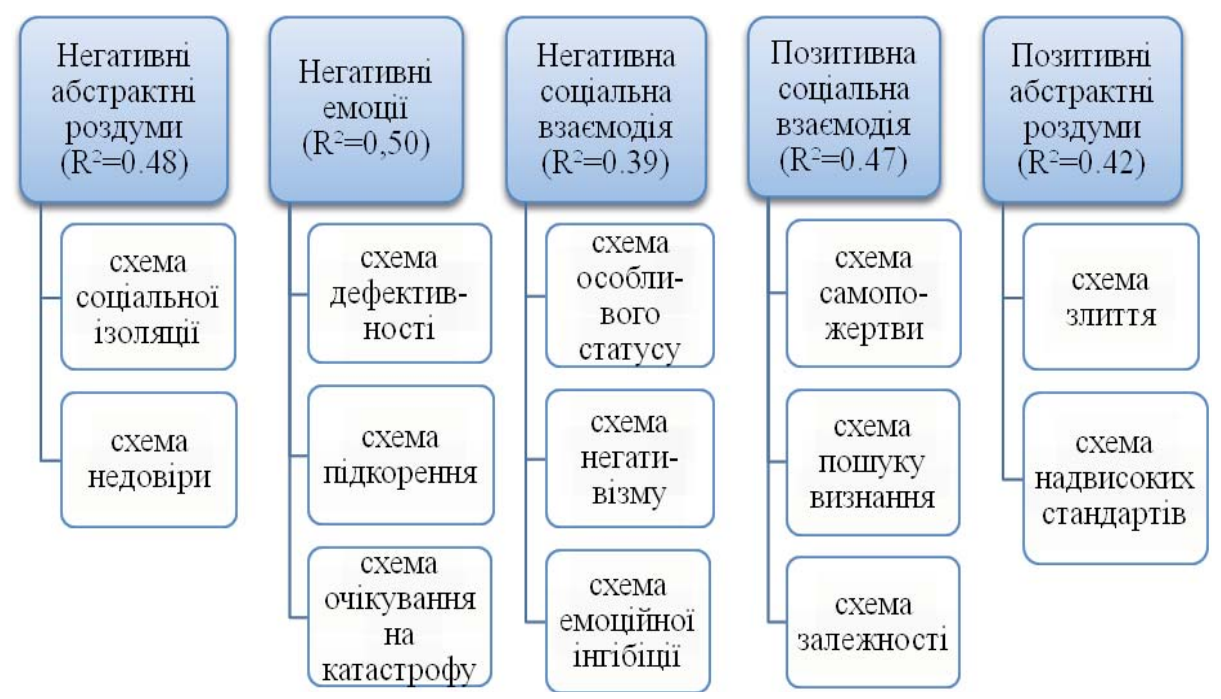

Рис. 1. Прогностичний потенціал наративних індикаторів для передбачення окремих дисфункиіийних когнітивних схем

За другою підкатегорією («позитивна соціальна взаємодія») також було отримано досить точний прогноз $\left(\mathrm{R}^{2}=0.47\right)$. При цьому, апелювання до приязних взаємин, опис ситуацій неформального спілкування 3 представниками референтної групи, змалювання загальної комунікативної активності $€$ характерним для осіб, які мають високі показники за такими схемами: самопожертви, пошуку визнання та залежності. Як видно, дві з трьох зазначених схем належать до категорії схем спрямованості на інших, що $є$ очікуваним і прогнозованим. Тобто особи, які мають дисфункційні переконання з приводу надмірної цінності міжособистісних взаємин, схильні приділяти цій темі значну увагу у власних персональних наративах. I, відповідно, наявність у тексті цих категорій може бути індикатором дії зазначених схем. 
Третя підкатегорія, яку ми розглянемо - «негативна соціальна взаємодія» - включає висловлювання, що описують ситуації комунікації, які стали травмуючими для автора, а також опис конфліктів та конфронтацій, що виникають в ході міжособистісних взаємин. Прогностичний потенціал тут нижчий, ніж за двома попередніми підкатегоріями, але тим не менш $\epsilon$ статистично значущим $\left(\mathrm{R}^{2}=0.39\right)$. Результати дослідження свідчать, що негативний досвід соціальної взаємодії схильні описувати ті особи, які мають високі показники за схемами особливого статусу, негативізму та емоційної інгібіції. Цікаво, що на відміну від попереднього випадку, жодна 3 даних схем не належить до категорії спрямованості на інших. Тобто негативний соціальний та комунікативний досвід воліють змальовувати особи, які в повсякденному житті прагнуть дистанціюватись від інших або ж зайняти стосовно них домінантну позицію. Часто саме це і стає передумовою виникнення негативного соціального досвіду.

Точність статистичного прогнозу за четвертою підкатегорією («позитивні абстрактні роздуми») $є$ достатньо високою $\left(\mathrm{R}^{2}=0.42\right)$. Дана підкатегорія включала висловлювання, які відображають міркування автора про навколишній світ, своє місце в ньому, загальні світоглядні та ціннісні ідеї i, як видно 3 назви, була позитивно забарвленою. Тобто висловлювання мали позитивний характер, а загальна картина світу описувалась 3 оптимістичних позицій. Наявність позитивних абстрактних роздумів є характерною для наративів осіб, які мають високі показники за схемами злиття та надвисоких стандартів. Це дає можливість припустити, що певний показовий оптимізм є одним 3 надвисоких стандартів, відповідати яким прагнуть такі особи.

Показник точності прогнозу за п’ятою підкатегорією («негативні абстрактні роздуми») $€$ ще більш високим, ніж попередній $\left(\mathrm{R}^{2}=0.48\right)$. Дана категорія $\epsilon$ типовою для наративів підлітків, які мають високі показники прояву таких схем: соціальної ізоляції, недовіри. Тобто, схильність особи до загальних роздумів про життя та влаштування навколишнього світу, які сповнені песимізму та негативізму і відображають знижений рівень домагань та переважне очікування небезпеки, може бути предиктором наявності в неї однієї зі схем втрати зв'язку та відкидання. Можемо припустити, що схильність до абстрактних роздумів при 
цьому $є$ певною формою компенсації нестачі довірчого інтимноособистісного спілкування.

Таким чином, аналізуючи персональні наративи підлітків 3 урахуванням визначених нами категорій (індикаторів), можна 3 високою мірою імовірності говорити про наявність в них 14 з 18 дисфункційних когнітивних схем.

\section{Висновки}

Отримані дані дозволили нам зробити висновок про те, що наявність у підлітка тих чи інших дисфункційних схем знаходить своє відображення в його особистих наративах. В ході емпіричного дослідження було виокремлено текстові категорії (індикатори), які вказують на наявність дисфункційних схем. Такими категоріями $\epsilon$ «соціальна взаємодія» (позитивна й негативна), «абстрактні роздуми» (позитивні й негативні) та «емоції й переживання» (негативні). Також було визначено прогностичну силу кожної категорії (індикатора) персональних наративів для передбачення наявності у мовця чотирнадцяти 3 вісімнадцяти дисфункційних когнітивних схем.

Відповідно, уважний аналіз персональних наративів підлітків дозволяє робити припущення про те, які саме дисфункційні схеми $\epsilon$ характерними для них. Такі відомості можуть бути корисними, передусім, для психопрофілактичної та психотерапевтичної роботи 3 даною категорією осіб. Адже ще на етапі збору первинної інформації фахівець-психолог, акцентуючи увагу на особистому тексті клієнта, може передбачити, яка дисфункційна схема (а відповідно і які глибинні переконання) властива клієнтові та, на основі отриманих знань вибудовувати власну стратегію взаємодії з ним.

Як було зазначено, статистичні дані, отримані в ході емпіричного дослідження, дозволяють проаналізувавши особистий наратив підлітка, з високою мірою імовірності прогнозувати наявність у нього однієї з чотирнадцяти дисфункційних схем. Чотири інші схеми (емоційної деривації, недостатнього самоконтролю, покинення i покарання) не знайшли свого відображення в тих категоріях контент-аналізу, які були визначені на початку дослідження. Тому актуальні перспективи подальшої наукової розробки даної проблеми 
ми вбачаємо в розширенні категоріальної структури контентаналізу, що дозволить віднайти індикатори чотирьох схем, які наразі залишаються нез'ясованими. Також доцільним є розширення вікового діапазону респондентів та перевірка гіпотези про наявність зв'язку між персональними текстами дорослих досліджуваних та притаманними їм дисфункційними схемами. Такі дослідження дозволять сформувати доказову емпіричну базу для психологічної роботи 3 дисфункційними схемами клієнтів з використанням методів наративної психотерапії.

Крім того, враховуючи різноспрямованість зв'язку між персональним наративом підлітка та його дисфункційними схемами, доцільно припустити, що модифікація цього наративу може пришвидшувати терапевтичну роботу, спрямовану на елімінацію негативного впливу дисфункційних схем на життя людини. Традиційно проблема роботи з персональними історіями клієнтів вирішується в межах наративної психотерапії. Проте, в даному випадку перед нами постають перспективи розробки методу цілеспрямованого психологічного впливу, що знаходитиметься на межі когнітивної та наративної психотерапії. Втім, розробці такого методу мають передувати ширші емпіричні дослідження, здатні сформувати грунтовний науковий фундамент для подальшої практичної роботи.

\section{Література}

Арнц, А. (2014). Схема-терапія: модель роботи з частками. Львів: Свічадо.

Василюк, О. (2014). Автобіографічний наратив як діагностичний інструментарій під час дослідженні травматичної пам'яті. East European Journal of Psycholinguistics, 1, 201-208.

Жорняк, Е.С. (2005). Нарративная психотерапия. Журнал практической психологии и психоанализа, 4, 75-87.

Зайцева, Ю.Е. (2016). Я-нарратив как инструмент конструирования идентичности: экзистенциально-нарративный подход. Вестник СПбГУ, 16(1), 17-24.

Засєкіна, Л.В. (2012). Наративний досвід vis-à-vis здоров’ю особистості. Психологічні перспективи, 19, 101-110.

Засєкіна, Л.В. (2009). Психологія значення: відбиття діяльнісного підходу у когнітивній парадигмі. Наукові записки Національного університету «Острозька академія», 12, 62-72.

Ионова, С.В., \& Штеба, А.А. (2019). Смешанные эмоции: к вопросу о лингвистической репрезентации и метязыке описания. Bonpocbl психолингвистики, 2(40), 63-81. https://doi.org/10.30982/2077-5911-2019-40-2-63-81 
Казанцева, Е.В. (2018). Психологический субстрат нарративной схемы. Психолог, 1, 39-48. https://doi.org/10.25136/2409-8701.2018.1.24412

Кубрак, Т.А. (2009). Интенция самопрезентации субъекта в вербальной коммуникации. Дисс. канд. психол. наук. Москва.

Литвиненко, О.О. (2014). Індивідуально-психологічні особливості сприймання літературного тексту. Дис. канд. психол. наук. Київ.

Масієнко, Ю.О. (2006). Структурно-динамічні ознаки «Я-тексту» особистості. Дис. канд. психол. наук. Київ.

Никитина, Е.С. (2015). О понятии нулевого смысла текста. Культурноисторическая психология, 11(2), 108-117. https://doi.org/10.17759/ chp. 2015110211

Федорова, Е.А. (2007). Личностные и ситуационные факторы выбора вербальных техник самопрезентации. Дисс. канд. психол. наук. Москва.

Чепелева, Н.В. (2010). Жизненный успех как нарратив. Успішність особистості: потенціал та обмеження (с. 251-254). Київ: НПУ ім. М.П. Драгоманова.

Юрьева, Н.М. (2018). Интерактивный компонент в механизме порождения нарратива детьми. Вопросы психолингвистики, 1(35), 115-125. https://doi. org/10.30982/2077-5911-2018-35-1-115-125

Bauer, J., \& McAdams, D. (2010). Eudaimonic growth: Narrative growth goals predict increases in ego development and subjective well-being 3 years later. Developmental Psychology, 46(4), 761-772. http://dx.doi.org/10.1037/a0019654

Bateman, A., \& Fonagy, P. (2009). Psychotherapy For Borderline Personality Disorder. N.Y.

Blenkiron, P. (2005). Stories and Analogies in Cognitive Behaviour Therapy: A Clinical Review. Behavioural and Cognitive Psychotherapy, 33, 45-54. https:// doi.org/10.1017/S1352465804001766

Dautenhahn, K. (2009). The Narrative Intelligence Hypothesis: In Search of the Transactional Format of Narratives in Humans and Other Social Animals. UK: University of Hertfordshire.

Harre, R. (2002). Cognitive Science. A Philosophical Introduction. SAGE Publications Ltd.

Hothorn, T., Hornik, K., \& Zeileis, A. (2006). Unbiased Recursive Partitioning: A Conditional Inference Framework. Journal of Computational and Graphical Statistics, 15(3), 33-45. https://doi.org/10.1198/106186006X133933

Loose, Ch., Meyer, F., \& Pietrowsky, R. (2018). The Dusseldorf Illustrated Schema Questionnaire for Children (DISC). Psicologia: Reflexão e Crítica, 31, 1-12. http://dx.doi.org/10.1186/s41155-018-0087-y

Sarbin, T. (1986). Narrative psychology: the storied nature of human conduct. Cambridge, Mass.: Harvard University Press.

Stephens, C., \& Breheny, M. (2015). Narrative Analysis in Psychological Research: An Integrated Approach to Interpreting Stories. Qualitative Research in Psychology, 10, 71-78. https://doi.org/10.1080/14780887.2011.586103

Van Dijk, T. (2008). Philosophy of Action and Theory of Narrative. USA: Edward Elgar Publishing, Inc.

Wooffitt, R. (2015). Conversation Analysis and Discourse Analysis. London. https:// doi.org/10.4135/9781849208765

Young, J., Klosko, J., \& Weishaar, M. (2003). Schema therapy. N.Y., London. 


\section{References}

Arntz, A. (2014). Skhema-terapiya: model roboty z chastkamy [Scheme-therapy: a model of work with particles]. Lviv: Svichado [in Ukrainian].

Vasylyuk, O. (2014). Avtobiohrafichnyy naratyv yak diahnostychnyy instrumentariy pid chas doslidzhenni travmatychnoyi pam'yati [An autobiographical narrative as a diagnostic tool in the study of traumatic memory]. East European Journal of Psycholinguistics, 1, 201-208 [in Ukrainian].

Zhornyak, Ye.S. (2005). Narrativnaya psikhoterapiya [Narrative psychotherapy]. Zhurnal prakticheskoy psikhologii $i$ psikhoanaliza - Journal of Practical Psychology and Psychoanalysis, 4, 75-87 [in Russian].

Zaytseva, Yu.E. (2016). YA-narratyv kak ynstrument konstruyrovanyya ydentychnosty: ekzystentsyalno-narratyvnyy podkhod [Self-narrative as a tool for constructing identity: an existential-narrative approach]. Vestnyk SPbHU - Vestnik of Saint Petersburg University, 16(1), 17-24 [in Russian].

Zasyekina, L.V. (2012). Naratyvnyy dosvid vis-à-vis zdorovyu osobystosti [Narrative experience vis-à-vis personality health]. Psykholohichni perspektyvy Psychological prospects, 19, 101-110 [in Ukrainian].

Zasyekina, L.V. (2009). Psykholohiya znachennya: vidbyttya diyalnisnoho pidkhodu $\mathrm{u}$ kohnityvniy paradyhmi [Psychology of meaning: reflection of the activity approach in the cognitive paradigm]. Naukovi zapysky Natsionalnyy universytet «Ostrozka akademiya» - Scientific notes of the National University "Ostroh Academy», 12, 62-72 [in Ukrainian].

Yonova, S.V., \& Shteba, A.A. (2019). Smeshannye émotsyy: k voprosu o lynhvystycheskoy reprezentatsyy y metyazyke opysanyya [Mixed emotions: on the question of linguistic representation and the language of description]. Voprosy psykholynhvystyky - Journal of Psycholinguistics, 2(40), 63-81. https://doi. org/10.30982/2077-5911-2019-40-2-63-81 [in Russian].

Kazantseva, Ye.V. (2018). Psikhologicheskiy substrat narrativnoy skhemy [The psychological substrate of the narrative scheme]. Psikholog - Psychologies, 1, 39-48. https://doi.org/10.25136/2409-8701.2018.1.24412 [in Russian].

Kubrak, T.A. (2009). Yntentsyya samoprezentatsyy subekta v verbalnoy kommunykatsyy [Intensity of self-presentation of a subject in verbal communication]. Candidate's thesis. Moscow [in Russian].

Lytvynenko, O.O. (2014). Indyvidualno-psykholohichni osoblyvosti spryymannya literaturnoho tekstu [Individual-psychological peculiarities of literary text perception]. Candidate's thesis. Kyiv [in Ukrainian].

Masiyenko, Yu.O. (2006). Strukturno-dynamichni oznaky «YA-tekstu» osobystosti [Structural and dynamic features of the «I-text» of personality]. Candidate's thesis. Kyiv [in Ukrainian].

Nikitina, Ye.S. (2015). O ponyatii nulevogo smysla teksta [On the concept of zero meaning of the text]. Kulturno-istoricheskaya psikhologiya - CulturalHistorical Psychology, 11(2), 108-117. https://doi.org/10.17759/chp.2015110211 [in Russian].

Fedorova, E.A. (2007). Lychnostnye y sytuatsyonnye faktory vybora verbalnykh tekhnyk samoprezentatsyy [Personal and situational factors for the choice of verbal techniques of self-presentation]. Candidate's thesis. Moscow [in Russian]. 
Chepyeleva, N.V. (2010). Zhyttyevyy uspikh yak naratyv [Life Success as a Narrative]. Uspishnist osobystosti: Potentsial ta obmezhennya - Success of personality: potential and limitations (pp. 251-254) [in Russian].

Yuryeva, N.M. (2018). Interaktivnyy komponent $\mathrm{v}$ mekhanizme porozhdeniya narrativa detmi [Interactive component in the mechanism of generation of narrative by children]. Voprosy psykholynhvystyky - Journal of Psycholinguistics, 1(35), 115125. https://doi.org/10.30982/2077-5911-2018-35-1-115-125 [in Russian].

Bauer, J., \& McAdams, D. (2010). Eudaimonic growth: Narrative growth goals predict increases in ego development and subjective well-being 3 years later. Developmental Psychology, 46(4), 761-772. http://dx.doi.org/10.1037/a0019654

Bateman, A., \& Fonagy, P. (2009). Psychotherapy For Borderline Personality Disorder. N.Y.

Blenkiron, P. (2005). Stories and Analogies in Cognitive Behaviour Therapy: A Clinical Review. Behavioural and Cognitive Psychotherapy, 33, 45-54. https:// doi.org/10.1017/S1352465804001766

Dautenhahn, K. (2009). The Narrative Intelligence Hypothesis: In Search of the Transactional Format of Narratives in Humans and Other Social Animals. UK: University of Hertfordshire.

Harre, R. (2002). Cognitive Science. A Philosophical Introduction. SAGE Publications Ltd.

Hothorn, T., Hornik, K., \& Zeileis, A. (2006). Unbiased Recursive Partitioning: A Conditional Inference Framework. Journal of Computational and Graphical Statistics, 15(3), 33-45. https://doi.org/10.1198/106186006X133933

Loose, Ch., Meyer, F., \& Pietrowsky, R. (2018). The Dusseldorf Illustrated Schema Questionnaire for Children (DISC). Psicologia: Reflexão e Crítica, 31, 1-12. http://dx.doi.org/10.1186/s41155-018-0087-y

Sarbin, T. (1986). Narrative psychology: the storied nature of human conduct. Cambridge, Mass.: Harvard University Press.

Stephens, C., \& Breheny, M. (2015). Narrative Analysis in Psychological Research: An Integrated Approach to Interpreting Stories. Qualitative Research in Psychology, 10, 71-78. https://doi.org/10.1080/14780887.2011.586103

Van Dijk, T. (2008). Philosophy of Action and Theory of Narrative. USA: Edward Elgar Publishing, Inc.

Wooffitt, R. (2015). Conversation Analysis and Discourse Analysis. London. https:// doi.org/10.4135/9781849208765

Young, J., Klosko, J., \& Weishaar, M. (2003). Schema therapy. N.Y., London.

\section{АНОТАЦІЯ}

Вступ. У статmі представлено результати дослідження персональних наративів підлітків, спрямованого на визначення специфічних текстуальних індикаторів, що можуть вказувати на прояв певних дисфункційних когнітивних схем. Загальна мета дослідження полягала у визначенні наративних індикаторів дисфункційних когнітивних схем підлітків та була досягнута за рахунок реалізації таких завдань, як: виокремлення конкретних текстових категорій (індикаторів), які б вказували на наявність дисфункційних схем та визначення прогностичної сили кожної категорії (індикатора) персональних наративів для 
передбачення наявності у мовця тієї чи іншої дисфункційної когнітивної схеми. В ході теоретичного аналізу було систематизовано підходи до розуміння персональних наративів та "я-текстів» особистості, узагальнено концепцію дисфункційних когнітивних схем, визначено текстуальні категорії, що можуть відображатись у наративах осіб, яким властиві певні дисфункційні схеми.

Meтоди. В якості методів емпіричного дослідження було використано Дюссельдорфський опитувальник схем для дітей $і$ контент-аналізу персональних наративів. Статистична обробка отриманих даних та визначення прогностичної сили кожної наративної категорії у передбаченні наявності когнітивних дисфункціїйних схем здійснювались за допомогою методу дерев рекурсивного ділення.

Результати. З'ясовано, що наявність певних категорій в персональних наративах підлітків дозволяє прогнозувати прояв у них окремих дисфункційних схем. Виокремлено наративні індикатори для передбачення чотирнадияти 3 вісімнадияти схем. Окреслено коло практичних шляхів застосування отриманих результатів. Визначено, що знання наративних індикаторів дисфункційних когнітивних схем може бути використано в межах психологічного консультування та терапії на етапі збору первинної інформації, а також в контексті цілеспрямованого психологічного впливу.

Висновки. Описано актуальні перспективи подальшої наукової розробки даної проблеми, котрі полягають в розширенні категоріальної структури контент-аналізу, що дозволить віднайти індикатори чотирьох схем, які наразі залишаються нез'ясованими, а також в розширенні вікового діапазону респондентів та перевірці гіпотези про наявність зв'язку між персональними текстами дорослих досліджуваних та притаманними їм дисфункційними схемами. Сформульовано припущення про те, що модифікація персонального наративу може пришвидшувати терапевтичну роботу, спрямовану на елімінацію негативного впливу дисфункційних схем на життя людини. При цьому, постають перспективи розробки методу цілеспрямованого психологічного впливу, що знаходитиметься на межі когнітивної та наративної психотерапії.

Ключові слова: наратив, дисфункційні схеми, глибинні переконання, підлітковий вік, контент-аналіз, наративна психотерапія.

Лозовая Ольга, Литвиненко Елена. Нарративные индикаторы дисфункциональных когнитивных схем подростков

\section{АННОТАЦИЯ}

Вступление. В статье представлены результаты исследования персональных нарративов подростков, направленного на определение специфических текстовых индикаторов, которые могут указывать на проявление определённых дисфункциональных когнитивных схем. Общая цель исследования заключалась в определении нарративных индикаторов дисфункциональных когнитивных схем подростков и была достигнута за счёт 
Narrative Indicators of Adolescents' Maladaptive Cognitive Schemas

реализации таких задач, как: выделение конкретных текстовых категорий (индикаторов), которые бы указывали на наличие дисфункциональных схем и определение прогностической силы каждой категории (индикатора) персональных нарративов для предсказания наличия у говорящего той или иной дисфункциональной когнитивной схемы. В ходе теоретического анализа систематизированы подходы к пониманию персональных нарративов и "я-текстов" личности, обобщена концепция дисфункциональных когнитивных схем и убеждений, определены текстуальные категории, которые могут отображаться в нарративах лии, которым присущи определённые дисфункциональные схемы.

Методы. В качестве методов эмпирического исследования были использованы Дюссельдорфский опросник схем для детей и контент-анализа персональных нарративов. Статистическая обработка полученных данных и определение прогностической силы каждой нарративной категории в определении наличия когнитивных дисфункциональных схем были реализованы с помощью метода деревьев рекурсивного деления.

Результаты. Установлено, что наличие определённых категорий в персональных нарративах подростков позволяет прогнозировать проявление у них отдельных дисфункциональных схем. Выделены нарративные индикаторы для предсказания четырнадцати из восемнадцати схем. Очерчен круг практических способов применения полученных результатов. Определено, что знания нарративных индикаторов дисфункциональных когнитивных схем может быть использовано в рамках психологчческого консультирования и терапии на этапе сбора первичной информации, а также в контексте целенаправленного психологического воздействия.

Выводы. Описаны актуальные перспективы дальнейшей научной разработки данной проблемы, заключающиеся в расширении категориальной структуры контент-анализа, позволяющем найти индикаторы четырёх схем, которые пока остаются невыясненными, а также в расширении возрастного диапазона респондентов и проверке гипотезы о наличии связи между персональными нарративами взрослых испытуемых и присущими им дисфункциональными схемами. Сфрормулировано предположение о том, что модификация персонального нарратива может ускорить терапевтическую работу, направленную на элиминацию негативного воздействия дисфункциональных схем на жизнь человека. При этом возникают перспективы разработки метода целенаправленного психологического воздействия на пересечении когнитивной и нарративной психотерапии.

Ключевые слова: нарратив, дисфункциональные схемы, глубинные убеждения, подростковый возраст, контент-анализ, нарративная психотерапия. 